\title{
ОСОБЛИВОСТІ ПЕРЕБІГУ ХВОРОБИ ЛАЙМА (БОРЕЛІОЗУ) У ДИТЯЧОМУ ВІЩІ
}

\author{
О. О. Пуренко, О. А. Прокопович \\ ДВНЗ «Тернопільський державний медичний університет \\ імені І. Я. Горбачевського МОЗ Украӥни»
}

У статті відображено особливості перебігу хвороби Лайма у дитячому віці.

\section{FEAUTURES OF CLINICAL MANIFESTATIONS OF LYME DISEASE (BORRELIOSIS) IN CHILDREN}

\author{
O. O. Purenko, O. A. Prokopovych
}

\section{Horbachevsky Ternopil State Medical University}

The article represents the feautures of clinical manifestations of Lyme disease in children.

Вступ. Вперше хвороба Лайма, або кліщовий бореліоз, з'явилася в Сполучених Штатах Америки в містечку з назвою Лайм у 1975 р. Тут зафіксували перші випадки цього захворювання у двох дітей.

Сполучені Штати Америки тепер далеко не єдина країна, де спостерігають хворобу Лайма, або бореліоз. Саме в США почалося вивчення цього захворювання, і визначення, від якого саме кліща виникає бореліоз. Вчений Віллі Бургдорфер вперше відокремив кліщів роду Borrelia burdorferi, за спірохетоподібними мікроорганізмами. В Україні за період 2000-2010 рр. захворюваність на Лайм-бореліоз зросла у 21,9 раза з 58 до 1275 випадків. Тенденцію до подальшого зростання прогнозують і надалі. Про це свідчить той факт, що за період 2011-2016 рр. по Україні зареєстровано 13061 випадків, тобто за більш короткий період часу захворюваність різко збільшилась [1].

Основна частина. Інфекційна хвороба передається людині під час присмоктування чорноногих кліщів до шкіри. Активність нападів припадає на квітень травень та серпень - вересень. Резервуаром і джерелом поширення хвороби Лайма серед дітей слугують домашні та дикі тварини. Після перенесеної хвороби Лайма в дитини виробляється нестійкий імунітет, а через кілька років можливе повторне зараження кліщовим бореліозом [2].

() О. О. Пуренко, О. А. Прокопович, 2018
За ступенем тяжкості патологічних реакцій захворювання може перебігати в легкій, середній, тяжкій та дуже тяжкій формі.

Інкубаційний період триває близько 7-14 днів. Після цього настає стадія локальної інфекції, що характеризується шкірними проявами та інтоксикаційним синдромом. На місці укусу кліща з'являється свербляча трохи болюча папула червоного кольору, схильна до периферійного росту. Еритема набуває вигляду кільця діаметром 10-20 см, що має яскраво-червоний віночок по краях і більш бліду центральну частину [3].

у більшості випадків мігруюча еритема при хворобі Лайма у дітей завершується спонтанно через 1-2 місяці, а на їі місці залишається слабка пігментація та лущення. У дітей прояви захворювання супроводжуються лихоманкою та ознобом, артралгією, болями в кістках та м'язах, вираженою слабкістю, головним болем. Протягом наступних 3-5 місяців розвивається дисемінована стадія хвороби Лайма. При безеритемній формі інфекції кліщовий бореліоз може відразу маніфестувати з системних проявів. Найчастіше на цій стадії розвивається ураження нервової та серцевосудинної системи [4]. Серед неврологічних синдромів для хвороби Лайма найтиповіші : серозний менінгіт, енцефаліт, периферійний радикулоневрит, неврит лицьового нерва, мієліт, церебральна атаксія. У цей період прояви хвороби Лайма в дитини можуть 
включати пульсуючий головний біль, світлобоязнь, міалгію, невралгію, значну стомлюваність, розлади сну та пам'яті, порушення шкірної чутливості та слуху, сльозотечу, периферійні паралічі та парези. У хронічну форму (стадію персистенції) захворювання переходить через 6-24 місяці, після гострої стадії. На пізньому періоді хвороби Лайма у дітей найчастіше виникають ураження шкіри у вигляді атрофічного акродерматиту, доброякісної лімфоплазії або ураження суглобів. Шкіра стає тонкою, зморшкуватою, на ній з'являються телеангіектазії та склеродермоподобні зміни. Доброякісна лімфоцитома має вигляд червонувато-ціанотичного вузла або бляшки 3 округлими обрисами. Зазвичай локалізується на шкірі обличчя, вушних раковин, пахової ділянки, а в окремих випадках може трансформуватися в злоякісну лімфому [5].

Зараз серед рекомендованих діагностичних тестів для визначення, чи є дитина або доросла людина хворою на бореліоз, відомий тест Вестерн-блот, що визначає антитіла, і більш загальний тест на антитіла.

Критерії вірогідного діагнозу хвороби Лайма:

1. У пацієнта розвивається типова кліщова мігруюча еритема у вигляді кільця розміром не менше 5 см із просвітленням у центрі, в ендемічних регіонах і у відповідний сезон.

2. За відсутності типової клінічної картини - наявність одного чи кількох типових нижченаведених синдромів за умови лабораторного підтвердження бореліозної інфекції:

- ураження нервової системи у вигляді серозного менінгіту, енцефаліту, менінгорадикуліту, полірадикулоневриту, невриту черепних нервів;

- ураження суглобів за типом моно- чи олігоартриту рецидивного чи хронічного характеру;

- міокардит (перикардит) із порушенням провідності за типом атріовентрикулярної блокади 2 чи 3 ступеня;

- поодинока лімфоцитома мочки вуха чи соска грудної залози;

• хронічний атрофічний акродерматит.

\section{СПИСОК ЛІТЕРАТУРИ}

1. Волоха А. П. Хвороба Лайма (кліщовий бореліоз) у дітей / А. П. Волоха // Інфекційні хвороби. - 2014. - № 1. С. 80-87.

2. Інфекційні хвороби у загальній практиці та сімейній медицині / за ред. М. А. Андрейчина. - Тернопіль : ТдМУ, 2007. - 500 c.

\section{Диференційної діагностики потребують:}

- гострі гарячкові стани на підґрунті системних захворювань сполучної тканини, гематологічної патології, вірусних і бактеріальних інфекцій;

- розсіяний склероз;

- радикулопатії різного рівня;

- менінгоенцефаліти іншої етіології;

- цереброваскулярні розлади.

Діти з хворобою Лайма підлягають госпіталізації в інфекційний стаціонар. Медикаментозну терапію проводять з урахуванням стадії захворювання. На ранній стадії зазвичай призначають антибіотики тетрациклінового ряду (тетрациклін, доксициклін) протягом 14 днів, можливе приймання амоксициліну. При переході захворювання в II або III стадію та розвитку суглобових, неврологічних та кардіологічних уражень доцільне використання пеніцилінів або цефалоспоринів протягом 21-28 днів. На тлі лікування антибіотиками може відзначатися реакція яришаГерксгеймера, що характеризується загостренням симптомів спірохетозу в зв'язку із загибеллю борелій та потраплянням у кров ендотоксинів. У такому випадку терапію антибіотиками на короткий час припиняють, а потім поновлюють в меншому дозуванні [6-8]. Патогенетичне лікування хвороби Лайма у дітей залежить від клінічних проявів та їх тяжкості. Так, при загальноінфекційних симптомах рекомендовано дезінтоксикаційну терапію, при артритах - НПЗ3, анальгетики, фізіотерапію, а при менінгіті - дегідратаційну терапію. При тяжкому системному перебігу захворювання призначають глюкокортикоїди внутрішньо або у вигляді внутрішньосуглобових ін'єкцій.

Висновки. Проблема бореліозу в дітей, зокрема ураження нервової системи при цій патології, $\epsilon$ надзвичайно актуальною й потребує проведення постійної санітарно-освітньої роботи серед населення, формування високої настороженості лікарів до цієї патології в ендемічних районах, удосконалення методів діагностики та лікувально-профілактичних заходів.

3. Хвороба Лайма на Тернопільщині / Н. А. Васильєва, О. Л. Івахів, В. О. Качор [та ін.] // Інфекційні хвороби. 2011. - № 2. - С. 50-53.

4. Шкільна М. І. Лайм-бореліоз у працівників лісових господарств Тернопільської області / М. І. Шкільна // Інфекційні хвороби. - 2016. - № 1 (83). - С. 36-40. 
5. Частота виявлення борелій і анаплазми у кліщів, вилучених від мешканців Тернопільської області / М. А. Андрейчин, М.І.Шкільна, С. О. Никитюк [та ін.] // Епідеміологічні та клінічні ускладнення інфекційних і паразитарних хвороб у сучасних умовах : тези Всеукр. наук.-практ. конф. інфекціоністів і пленуму ГО ВАІ, 5-6 жовтня 2017 р., Житомир. - Тернопіль : Укрмедкнига, 2017. - C. 9-11.
6. Акимов И. А. Иксодовые клещи городских ландшафтов г. Киева / И. А. Акимов, И. В. Небогаткин. - К., 2016. - 156 c.

7. Awareness of tick-borne bacterial infection in the students of non-medical universities in Ternopil region (Western Ukraine) /

8. S. Nykytyuk, A. Pańczuk, M. Shkilna [et al.] // Health Problems of Civilization. - 2017. - Vol. 11, Issue 2. - P. 99-102. 